\title{
THE EFFECTIVENESS OF DIFFERENT HERBICIDES IN THE DESTRUCTION OF BANANA Xanthomonas WILT INFECTED PLANTS
}

\author{
G. BLOMME, L.F. TURYAGYENDA, H. MUKASA and S. EDEN-GREEN ${ }^{1}$ \\ Bioversity Uganda P. O. Box 24384, Kampala, Uganda \\ ${ }^{1}$ EG Consulting. 470 Lunsford Lane, Larkfield, Kent ME20 6JA, UK
}

\begin{abstract}
Early detection followed by the destruction of infected mats is one of the recommended and effective methods of controlling banana Xanthomonas wilt. As manual destruction is very tedious and time consuming, herbicide injections in the pseudostem or the stump were evaluated as a suitable alternative. The study was carried out in Luwero district in central Uganda. Herbicide injections were made on 'Pisang Awak' plants (Musa ABB group) using different concentrations of Roundup and 2,4-D at a pseudostem height of 30 and $100 \mathrm{~cm}$. In addition, the herbicide was injected in the centre (diameter-wise) and in the peripheral part of the pseudostem (tangentialwise). Herbicide applications into the stump were also evaluated. All plants (100\%) injected with 2,4-D had fallen and started rotting by three weeks after application. However, at three weeks, none of the plants treated with Roundup, regardless of the concentration and the height of injection had died. Similarly plants injected with 2,4-D had less re-sprouting compared to plants treated with Roundup. Therefore, 2,4-D is more effective than Roundup in destroying 'Pisang Awak' plants and in suppressing the re-sprouting of lateral shoots. Since 2,4-D is also cheaper than Roundup it is recommended for use on small-scale plantations. At least $1.6 \mathrm{ml}$ of the original concentrate of 2,4-D and $2.0 \mathrm{ml}$ of the original concentrate of Roundup needs to be applied per mature plant. The most effective pseudostem injection height was found to be $100 \mathrm{~cm}$. The angle of injection whether peripherally or central and the plant growth stage did not affect the herbicides' efficiency. The results also showed that pseudostem injections are more effective than stump herbicide applications.
\end{abstract}

Key Words: Banana bacterial wilt, herbicide, 'Pisang Awak', pseudostem injection, stump application

\section{RÉSUMÉ}

Tôt la détection suivie par la destruction de tapis infectés est une des méthodes recommandées de contrôle efficaces de flanchent de Xanthomonas de banane. Comme la destruction manuelle est très ennuyeuse et le temps consommation des injections d'herbicide dans le pseudostem ou la souche ont été évaluées comme une alternative convenable. L'étude a été exécutée dans le quartier de Luwero en Ouganda central. Les injections d'herbicide ont été faites sur < Pisang Awak > les plantes (le groupe d'ABB de Musa) utilisant des concentrations différentes de Rassemblement et 2,4-D à une hauteur de pseudostem de 30 et $100 \mathrm{~cm}$. Par ailleurs, l'herbicide a été injecté au centre (diamètre-sage) et dans la partie périphérique du pseudostem (tangentiel-sage). Les applications d'herbicide dans la souche ont été aussi évaluées. Toutes les plantes (100\%) injecté avec 2,4-D était tombé et avait commencé à pourrir après trois semaines d'application. Cependant, à trois semaines, aucun des plantes traitées avec le Rassemblement, sans tenir compte de la concentration et la hauteur d'injection n'était mort. De même les plantes injectées avec 2,4-D ont au moins re-poussées en comparaison avec des plantes traitées avec le Rassemblement. Donc, 2,4-D est plus efficace que le Rassemblement des plantes < Pisang Awak > et en éliminant le re-pousses latéral des rejetons. Puisque 2,4-D est aussi plus bon marché que le Rassemblement qu'il est recommandé pour l'usage sur les plantations à petite échelle. Au moins 1,6 ml du concentré original de 2,4-D et 2,0 ml du concentré original de besoins de Rassemblement être appliqué par la plante mûre. La plus efficace injection pseudostem été trouvée pour être $100 \mathrm{~cm}$. L'angle d'injection si 
périphérique ou central et l'étape de croissance de la plante n'ont pas affecté l'efficacité des herbicides >. Les résultats ont montré aussi que les injections de pseudostem sont plus efficaces que d'applications d'herbicide à la souche.

Mots Clés: La banane bactérienne flanche, l’herbicide, « Pisang Awak >, l’injection de pseudostem, l'application de souche

\section{INTRODUCTION}

Banana bacterial wilt caused by Xanthomonas campestris pv. musacearum is a new devastating disease of banana in the east African region (Tushemereirwe et al., 2003). It is a vascular disease that results in permanent wilting and eventual death of the banana plant. It was initially identified in Ethiopia in the 1960s on Ensete ventricosum (a close relative of banana) (Yirgou and Bradbury, 1968, 1974). The disease emerged in Mukono district of Uganda in 2001 (Tushemereirwe et al., 2003) and has now spread to all banana growing districts of the country. The disease attacks all banana cultivars and results in total yield loss once it establishes itself. Infected plants are a source of inoculum and the pathogen is spread by insect vectors and farm tools. Musa genotypes belonging to the ABB genome group are highly susceptible to insect vector transmission. Early detection followed by the destruction of infected mats is one of the recommended and effective methods of controlling the disease. However, manual removal of infected mats is very tedious and time consuming. In addition, in areas of high disease incidence farmers continue to borrow farm and processing tools. The majority of farmers controlling the disease through manual removal also do not disinfect their garden tools. They find disinfection by heating above a fire cumbersome while chemical disinfection is said to be expensive. There is therefore a need for other easy and affordable methods to destroy infected mats. Herbicide injections in pseudostems or stump applications are proposed as alternatives. The use of herbicides may significantly reduce the time needed to kill off infected mats/plantations and may also reduce labour costs. In addition, the systemicity of the herbicides may kill the corms and prevent unwanted re-sprouting.
Herbicides have been used previously to destroy infected banana plants. In north Queensland, for example, glyphosate pseudostem injections have been used for many years to eradicate old or diseased banana (Musa AAA group) fields (Lindsay et al., 2003). Similarly in Martinique, the same herbicide has been used to kill off Cavendish plants (Musa AAA group) in preparation for fallow (Quénéhervé, Pers. comm). It has also been used in Hawaii to kill banana bunchy top infected plants (Musa AAA group) by injecting it at a height of at least one foot above the ground (Sommer, 2000; Anonymous, 2004).

On the other hand, 2,4-dichlorophenoxyacetic acid (2,4-D) has been used in Queensland, New South Wales and Israel for de-suckering (Robinson, 1995). Herbicide impregnated bamboo sticks or wooden pins have been used to kill banana plants in Brazil and the Philippines (Martinez et al., 1988). Paraquat has also been used in the past, but recent research has shown that this herbicide can be hazardous, especially under poorly-controlled conditions in developing countries. Public interest groups have called for its use to be phased out (Anonymous, 2002). Using herbicide injections to destroy bananas has several advantages. First the systemic nature of herbicides means that the whole plant, including the corm, dies and decays in a short time. In contrast, during manual removal or when using a tractor with a set of trailing discs corm pieces can remain in the soil and this could lead to unwanted re-sprouting. The herbicide equipment needed for herbicide application is simple, affordable and requires little skill to operate by farm staff.

Despite their proven effectiveness to destroy infected banana plants and old plantations in other countries, herbicides have not been thoroughly evaluated in Uganda for their effectiveness in destroying banana bacterial wilt 
infected mats. Since banana is mainly grown by poor small-scale farmers, determining the minimum effective amount of herbicide is important. The objectives of this study were therefore to: determine the optimum concentration and mode of application of glyphosate (Roundup) and 2,4-D for killing off banana Xanthomonas wilt infected mats; determine whether re-sprouting of lateral shoots occurs on herbicide treated banana plants; and determine the most cost-effective herbicide for use on small-scale farms.

\section{MATERIALS AND METHODS}

\section{Experimental site, genotypes and herbicides}

used. The study was carried out on-farm in Zirobwe sub-county of Luwero district in central Uganda. Zirobwe has been severely hit by the banana bacterial wilt epidemic mainly because the majority of farmers do not practice de-budding and largely cultivate the 'Pisang Awak' ('Kayinja') variety (Musa ABB group) which is particularly susceptible to floral infection (Eden-Green, 2004). 'Pisang Awak' was used in this study. Two types of herbicides; 2,4-D and Roundup were used. 2, 4-D is a systemic, selective soluble liquid herbicide used for the control of broad-leaved weeds in maize, wheat, barley sorghum, rice, sugarcane and grassland areas. Once absorbed 2,4-D is translocated within the plant and accumulates at the growing points of roots and shoots where it inhibits growth. Locally available preparations of this herbicide contain $720 \mathrm{gl}^{-1} 12$, 4-D amine salts. 'Roundup' is a post-emergence systemic and non-selective foliar herbicide used for the control of annual and pernnial grasses and broadleaf weeds, including kikuyou grass, couch and water grass in coffee, tea and other plantation crops, under minimum or zero tillage systems in pasture and stubbles, in forest sites and for industrial and aquatic weed control. This herbicide contains $480 \mathrm{gl}^{-1}$ IPA salt of $\mathrm{N}$ phosphonomethylglycinde (equivalent to $360 \mathrm{~g}$ $\mathrm{l}^{-1}$ glyphosate.

\section{Herbicide dilution and mode of application.} Roundup and 2, 4-D were diluted in water at thirteen different concentrations by dissolving 0.4, 0.6, 0.8, 1.1, 1.2, 1.6, 1.7, 2.0, 2.3, 2.9, 3.4, 4.5,
$5.7 \mathrm{ml}$ of the original concentrate of the herbicide in water to make $20 \mathrm{ml}$ of solution. The $20 \mathrm{ml}$ solution was injected into the pseudostem at 30 $\mathrm{cm}$ and $100 \mathrm{~cm}$ above ground level using a $60 \mathrm{ml}$ syringe fitted with a $10 \mathrm{~cm}$ long plastic needle. Twelve mature plants or maiden suckers with a height of more than 2 meter were selected and assessed for each concentration and for each herbicide. Before injection a $15 \mathrm{~cm}$ deep hole was made in the pseudostem at an angle of $45^{\circ}$ using a sharp metal rod with a diameter of $15 \mathrm{~mm}$. The herbicide solution was injected 5 minutes later after exudation of sap/latex from the hole had ceased. A single hole, and thus a single injection was administered per plant. This trial was replicated on a second 'Pisang Awak' plantation and plants were monitored weekly up to 10 weeks after herbicide injection. No injections were made higher up the pseudostem as making the hole becomes more impractical and there is an additional risk that herbicide drops may come in contact with eyes or mouth during application.

Angle of injection. In addition, the study also assessed the effective angle for injecting the herbicide into the banana pseudostem. Mature plants in the vegetative and reproductive stage were injected at $100 \mathrm{~cm}$ pseudostem height with Roundup and 2,4-D in the central (diameter-wise injection) and peripheral part of the pseudostem (tangential-wise injection) using $1.6 \mathrm{ml}$ of the original concentrate of 2,4-D and $2.0 \mathrm{ml}$ of the original concentrate of Roundup per plant diluted with water to $20 \mathrm{ml}$. 15 plants in the vegetative phase and 15 plants in the reproductive phase were used for the tangential and diameter-wise injections for each of the two herbicides. The injected plants were monitored for a period of 10 weeks.

Stump application. In addition to pseudostem herbicide injections, stump (i.e. base of the plant after the pseudostem was cut down) applications were carried out. Diseased mats of 'Pisang Awak' were randomly selected on farmers' fields and the pseudostem of the mother plant cut with a machete at soil level. A small hole $(3 \times 3 \times 3 \mathrm{~cm})$ was made in the middle of the cut surface and 1.0, 1.5 and $2.0 \mathrm{ml}$ of undiluted Roundup and 2,4-D were added. The lateral shoots were not cut down. 
Five mature plants were assessed per applied volume of each undiluted herbicide and there were 2 replications located on two different farms. Plants were monitored weekly up to 10 weeks after herbicide application.

\section{RESULTS AND DISCUSSION}

The results on the effectiveness of the herbicide injections after 3 weeks after application (WAA) and 6WAA are presented in Tables 1 and 2, respectively. Results obtained after 3WAA showed that 2,4-D was significantly more effective than Roundup. By 3WAA all the plants injected with 2,4-D had collapsed and started rotting, regardless of the height of injection and herbicide concentration (Table 1). None of the plants injected at $30 \mathrm{~cm}$ above the ground with Roundup had shown symptoms by 3WAA, although a few plants injected at $100 \mathrm{~cm}$ had died. The height of injection and herbicide concentration did not significantly affect the action of 2,4-D. Although

TABLE 1. Number of plants killed by different herbicides at 3 weeks after application at different heights using different quantities of original concentrate of the herbicide

\begin{tabular}{|c|c|c|c|c|}
\hline \multirow{2}{*}{$\begin{array}{l}\mathrm{ml} \text { of original } \\
\text { concentrate }\end{array}$} & \multicolumn{2}{|c|}{$2,4 \mathrm{D}$} & \multicolumn{2}{|c|}{ Roundup } \\
\hline & At $30 \mathrm{~cm}$ & At $100 \mathrm{~cm}$ & At $30 \mathrm{~cm}$ & At $100 \mathrm{~cm}$ \\
\hline 0.4 & $12.0 \pm 0.0$ & $12.0 \pm 0.0$ & $0.0 \pm 0.0$ & $2.4 \pm 0.0$ \\
\hline 0.6 & $12.0 \pm 0.0$ & $12.0 \pm 0.0$ & $0.0 \pm 0.0$ & $2.4 \pm 0.0$ \\
\hline 0.8 & $12.0 \pm 0.0$ & $12.0 \pm 0.0$ & $0.0 \pm 0.0$ & $2.4 \pm 0.0$ \\
\hline 1.1 & $12.0 \pm 0.0$ & $12.0 \pm 0.0$ & $0.0 \pm 0.0$ & $2.4 \pm 0.0$ \\
\hline 1.2 & $12.0 \pm 0.0$ & $12.0 \pm 0.0$ & $0.0 \pm 0.0$ & $2.4 \pm 0.0$ \\
\hline 1.6 & $12.0 \pm 0.0$ & $12.0 \pm 0.0$ & $0.0 \pm 0.0$ & $2.4 \pm 0.0$ \\
\hline 1.7 & $12.0 \pm 0.0$ & $12.0 \pm 0.0$ & $0.0 \pm 0.0$ & $2.4 \pm 0.0$ \\
\hline 2.0 & $12.0 \pm 0.0$ & $12.0 \pm 0.0$ & $0.0 \pm 0.0$ & $2.4 \pm 0.0$ \\
\hline 2.3 & $12.0 \pm 0.0$ & $12.0 \pm 0.0$ & $0.0 \pm 0.0$ & $2.4 \pm 0.0$ \\
\hline 2.9 & $12.0 \pm 0.0$ & $12.0 \pm 0.0$ & $0.0 \pm 0.0$ & $2.4 \pm 0.0$ \\
\hline 3.4 & $12.0 \pm 0.0$ & $12.0 \pm 0.0$ & $0.0 \pm 0.0$ & $2.4 \pm 0.0$ \\
\hline 4.5 & $12.0 \pm 0.0$ & $12.0 \pm 0.0$ & $0.0 \pm 0.0$ & $2.4 \pm 0.0$ \\
\hline 5.7 & $12.0 \pm 0.0$ & $12.0 \pm 0.0$ & $0.0 \pm 0.0$ & $2.4 \pm 0.0$ \\
\hline
\end{tabular}

TABLE 2. Number of plants killed by different herbicides at 6 weeks after application at different heights using different quantities of original concentrate of the herbicide

\begin{tabular}{llllll}
\hline ml of original & \multicolumn{2}{c}{$2,4 \mathrm{D}$} & & \multicolumn{2}{c}{ Roundup } \\
\cline { 2 - 3 } \cline { 5 - 6 } concentrate & At $30 \mathrm{~cm}$ & At $100 \mathrm{~cm}$ & & At $30 \mathrm{~cm}$ & At $100 \mathrm{~cm}$ \\
\hline 0.4 & $12.0 \pm 0.0$ & $12.0 \pm 0.0$ & $2.0 \pm 0.0$ & $4.8 \pm 0.0$ \\
0.6 & $12.0 \pm 0.0$ & $12.0 \pm 0.0$ & & $5.0 \pm 1.0$ & $4.8 \pm 0.0$ \\
0.8 & $12.0 \pm 0.0$ & $12.0 \pm 0.0$ & & $2.0 \pm 0.0$ & $7.2 \pm 0.0$ \\
1.1 & $12.0 \pm 0.0$ & $12.0 \pm 0.0$ & & $4.0 \pm 2.0$ & $7.2 \pm 0.0$ \\
1.2 & $12.0 \pm 0.0$ & $12.0 \pm 0.0$ & $3.5 \pm 1.0$ & $4.8 \pm 2.4$ \\
1.6 & $12.0 \pm 0.0$ & $12.0 \pm 0.0$ & & $2.0 \pm 0.0$ & $7.2 \pm 0.0$ \\
1.7 & $12.0 \pm 0.0$ & $12.0 \pm 0.0$ & & $4.0 \pm 0.0$ & $7.2 \pm 0.0$ \\
2.0 & $12.0 \pm 0.0$ & $12.0 \pm 0.0$ & $6.0 \pm 0.0$ & $7.2 \pm 0.0$ \\
2.3 & $12.0 \pm 0.0$ & $12.0 \pm 0.0$ & $4.0 \pm 0.8$ & $9.6 \pm 0.0$ \\
2.9 & $12.0 \pm 0.0$ & $12.0 \pm 0.0$ & $6.0 \pm 0.0$ & $4.8 \pm 0.0$ \\
3.4 & $12.0 \pm 0.0$ & $12.0 \pm 0.0$ & $4.0 \pm 2.0$ & $12.0 \pm 0.0$ \\
4.5 & $12.0 \pm 0.0$ & $12.0 \pm 0.0$ & $6.0 \pm 0.0$ & $9.6 \pm 0.0$ \\
5.7 & $12.0 \pm 0.0$ & $12.0 \pm 0.0$ & $8.5 \pm 0.5$ & $2.4 \pm 0.0$ \\
\hline
\end{tabular}


2,4-D concentrations did not significantly differ among themselves in killing plants, concentrations of $1.6 \mathrm{ml}$ and above, were observed to kill plants faster than the lower concentrations. Plants treated with at least $1.6 \mathrm{ml}$ of the original concentrate of 2,4-D per mature plant, irrespective of the height of injection, started falling on the ground at 2 WAA. The corms of treated plants snapped at soil level at 2 WAA. This suggests that for cost-effective results with 2,4-D, $1.6 \mathrm{ml}$ of the original herbicide concentrate is optimum.

Similarly, there was no significant effect of concentration on the action of Roundup. However, the height of injection significantly affected the effectiveness of Roundup (Table 1). No plants injected at $30 \mathrm{~cm}$ above the ground had shown symptoms by 3WAA. However, injections made $100 \mathrm{~cm}$ above the ground, irrespective of the concentration used, had at least 2.4 plants dead by 3WAA. The apparent slower action when Roundup was injected at 30 $\mathrm{cm}$ pseudostem height could be linked to the dense pseudostem tissue close to ground level and the proximity to the compact corm tissue. It was reported that in Martinique, injections in the corm were almost impossible due to the high density of the tissue. In Martinique, herbicide injections are carried out in the pseudostems, around $100 \mathrm{~cm}$ from the soil level as it is also the most convenient height for workers to do 2000 to 2500 injections per hectare daily.

In a similar pattern, at 6WAA, plants injected with Roundup at a height of $100 \mathrm{~cm}$ had more deaths than those injected at $30 \mathrm{~cm}$ (Table 2). This suggests that for better results with Roundup injections should be done in the pseudo-stem at a height of $100 \mathrm{~cm}$ from the ground. At 6WAA injections at $30 \mathrm{~cm}$ pseudostem height had a mean death of about 4.4 plants, while injections at $100 \mathrm{~cm}$ had a mean of 6.8 plants killed by Roundup. At $30 \mathrm{~cm}$ this mean was obtained with $2.0 \mathrm{ml}$ of the injected herbicide, while lower concentrations had fewer deaths. At $100 \mathrm{~cm}$ the mean was obtained when at least $0.8 \mathrm{ml}$ of the herbicide was injected (Table 2). This suggests that when $100 \mathrm{~cm}$ is used as the height of injection, less herbicide is needed, making it more economical for small-scale farmers.

The effect of Roundup was monitored up to 10 WAA. Except for $2.0 \mathrm{ml}$ of the herbicide, none of the concentrations had completely killed all the plants by 10 WAA (Table 3 ). All this suggests that Roundup is less effective in killing banana plants. This is contrary to earlier studies by Sommer (2000), Lindsay et al. (2003) and Anonymous (2004) who reported strong effects of this herbicide on bananas (Musa AAA group). Roundup is less effective, at least on 'Pisang Awak' (an ABB type banana) and $2.0 \mathrm{ml}$ of

TABLE 3. The effect of herbicide concentration on killing of plants and re sprouting at 10 weeks after application

\begin{tabular}{lcccr}
\hline $\begin{array}{l}\text { ml of original } \\
\text { concentrate }\end{array}$ & $\begin{array}{c}\text { Plants killed } \\
\text { by 2,4-D }\end{array}$ & $\begin{array}{c}\text { Plants killed } \\
\text { by Roundup }\end{array}$ & $\begin{array}{c}\text { Number of suckers } \\
\text { re-sprouting in 2,4-D } \\
\text { treated plants }\end{array}$ & $\begin{array}{c}\text { Number of suckers } \\
\text { re-sprouting in Roundup } \\
\text { treated plants }\end{array}$ \\
\hline 0.4 & $12.0 \pm 0.0$ & $4.8 \pm 1.6$ & $2.4 \pm 0.4$ & $2.2 \pm 0.2$ \\
0.6 & $12.0 \pm 0.0$ & $7.2 \pm 1.6$ & $2.6 \pm 0.4$ & $1.2 \pm 0.4$ \\
0.8 & $12.0 \pm 0.0$ & $1.2 \pm 0.4$ & $1.7 \pm 0.4$ & $1.9 \pm 0.6$ \\
1.1 & $12.0 \pm 0.0$ & $4.8 \pm 1.6$ & $2.4 \pm 0.4$ & $2.2 \pm 0.4$ \\
1.2 & $12.0 \pm 0.0$ & $4.8 \pm 0.7$ & $0.5 \pm 0.3$ & $1.8 \pm 0.2$ \\
1.6 & $12.0 \pm 0.0$ & $9.6 \pm 0.8$ & $0.0 \pm 0.0$ & $2.2 \pm 0.7$ \\
1.8 & $12.0 \pm 0.0$ & $8.4 \pm 1.2$ & $0.7 \pm 0.5$ & $0.5 \pm 0.3$ \\
2.0 & $12.0 \pm 0.0$ & $12.0 \pm 0.0$ & $0.2 \pm 0.2$ & $1.4 \pm 0.5$ \\
2.2 & $12.0 \pm 0.0$ & $9.6 \pm 0.8$ & $1.7 \pm 0.5$ & $1.9 \pm 0.6$ \\
2.4 & $12.0 \pm 0.0$ & $6.0 \pm 1.2$ & $0.0 \pm 0.0$ & $2.2 \pm 0.8$ \\
2.9 & $12.0 \pm 0.0$ & $8.4 \pm 1.2$ & $0.0 \pm 0.0$ & $1.7 \pm 0.5$ \\
3.3 & $12.0 \pm 0.0$ & $4.8 \pm 0.0$ & $0.7 \pm 0.5$ & $1.2 \pm 0.5$ \\
4.4 & $12.0 \pm 0.0$ & $9.6 \pm 0.8$ & $0.0 \pm 0.0$ & $1.9 \pm 0.6$ \\
5.6 & $12.0 \pm 0.0$ & $8.4 \pm 1.2$ & $0.0 \pm 0.0$ & $1.0 \pm 0.5$ \\
\hline
\end{tabular}


undiluted concentrate per plant was the optimum for Roundup.

The effect of the two herbicides on resprouting was also evaluated. The results revealed that 2,4-D was more effective in suppressing re-sprouting than Roundup. There was a significant influence of the herbicide concentration on sucker suppression. With 2,4$\mathrm{D}$, concentrations lower than $1.6 \mathrm{ml}$ of the original concentrate resulted in more suckers resprouting from the treated plants (Table 3 ). This suggests that lower concentrations of 2,4-D may not effectively suppress the re-sprouting of suckers though they may result in the death of the injected plants. However, concentrations of $1.6 \mathrm{ml}$ or higher suppressed re-sprouting of suckers from the treated plants and in most cases completely suppressed re-sprouting. The concentrations of $1.6 \mathrm{ml}$ and higher did not significantly differ from each other in suppression of sprouting . This suggests that $1.6 \mathrm{ml}$ of 2,4-D is the most optimum for suppressing re-sprouting of suckers in banana plants.

No complete suppression of re-sprouting was observed in plants treated with Roundup. Sucker growth could not be prevented even when the plants were injected with the highest doses of Roundup. Earlier studies by Sommer (2000), Lindsay et al. (2003) and Anonymous (2004) had suggested that Roundup has strong effects on AAA bananas. Contrary to this, Roundup was less effective, at least on 'Pisang Awak' (ABB) in suppressing re-sprouting.

\section{Angle of injection: peripheral and central pseudostem injections. Analysis of variance (ANOVA) indicated that the two herbicides significantly $(\mathrm{P}=0.05)$ differed in their effectiveness in killing and suppressing suckering (Table 4). Plants treated with 2,4-D regardless of the angle of injection and the growth stage had significantly more deaths $(15.0 \pm 0.0)$ than those treated with Roundup (9.5 \pm 1.6$)$ (Table 5). No new suckers were recorded on plants treated with 2,4- $\mathrm{D}$ after the herbicide application while plants treated with Roundup had 2.0 \pm 0.4 new suckers developing (Table 5). This further confirms that 2,4-D is more effective in killing and suppressing banana sucker development than Roundup.}

TABLE 4. ANOVA for the effect of herbicide, angle of injection and growth stage on death and suckering of the treated plants

\begin{tabular}{lllcc}
\hline Source & & MS & F-Value & P-Value \\
\hline Herbicide & Death of plants & 60.5 & 14.67 & 0.0186 \\
& Suckering & 7.72245 & 28.8 & 0.0058 \\
\multirow{2}{*}{ Angle of injection } & & & 1.09 & 0.3552 \\
& Death of plants & 4.5 & 1.61 & 0.2729 \\
& Suckering & 0.43245 & 1.94 & 0.2362 \\
Growth stage & Death of plants & 8 & 1.86 & 0.2438 \\
& Suckering & 0.5 & & \\
\hline
\end{tabular}

TABLE 5. Mean plant death and suckering according to herbicide, angle of injection and plant growth stage

\begin{tabular}{llcc}
\hline Effect & & Mean plant death & Mean suckering \\
\hline Herbicide & $2,4-\mathrm{D}$ & $15.0 \pm 0.0$ & $0.0 \pm 0.0$ \\
& Roundup & $9.5 \pm 1.6$ & $2.0 \pm 0.4$ \\
\multirow{3}{*}{ Angle of injection } & Central/diameter-wise & $11.5 \pm 2.4$ & $1.3 \pm 0.8$ \\
& Peripheral/tangential-wise & $13.0 \pm 1.2$ & $0.8 \pm 0.5$ \\
Growth stage & & & $1.3 \pm 0.7$ \\
& Reproductive & $13.3 \pm 1.0$ & $0.8 \pm 0.5$ \\
\hline
\end{tabular}


Herbicides in the destruction of banana Xanthomonas wilt

TABLE 6. Status of the treated corms and lateral shoots at 3 and 6 WAA on stumps (averages of 10 plants)

\begin{tabular}{|c|c|c|c|c|c|c|c|}
\hline \multirow[t]{2}{*}{ Herbicide } & \multirow{2}{*}{$\begin{array}{c}\text { ml of } \\
\text { original } \\
\text { concentrate }\end{array}$} & \multicolumn{3}{|c|}{3 WAA } & \multicolumn{3}{|c|}{ 6WAA } \\
\hline & & $\begin{array}{l}\text { Condition of } \\
\text { the mother } \\
\text { corm }{ }^{1}\end{array}$ & $\begin{array}{l}\text { Condition of } \\
\text { the suckers }\end{array}$ & $\begin{array}{l}\text { Signs of } \\
\text { re-sprouting } \\
\text { on the sucker } \\
\text { corms }^{3}\end{array}$ & $\begin{array}{l}\text { Condition of } \\
\text { the mother } \\
\text { corm }{ }^{1}\end{array}$ & $\begin{array}{l}\text { Condition of } \\
\text { the suckers }\end{array}$ & $\begin{array}{l}\text { Signs of } \\
\text { re-sprouting } \\
\text { on the sucker } \\
\text { corms }^{3}\end{array}$ \\
\hline \multirow{3}{*}{ Roundup } & 2.0 & 0 & 1.4 & 0 & 0 & 1.1 & 0.5 \\
\hline & 1.5 & 0 & 1.1 & 0 & 0 & 1.3 & 0.5 \\
\hline & 1.0 & 0 & 1.8 & 0 & 0 & 1.8 & 0.6 \\
\hline \multirow[t]{3}{*}{ 2,4-D } & 2.0 & 0 & 0 & 1 & 0 & 0 & 0.8 \\
\hline & 1.5 & 0 & 0 & 1 & 0 & 0 & 1 \\
\hline & 1.0 & 0 & 0 & 1 & 0 & 0 & 1 \\
\hline
\end{tabular}

1: 0 : rotten corm; 1 : live corm; $2: 0$ : dead sucker(s); 1 : recovering sucker(s); $2:$ healthy sucker(s); $3: 0:$ absent; 1 : present

Both the angle of injection (central or peripheral) and the growth stage did not significantly influence the herbicide’s efficiency in killing plants or suppressing sucker development (Table 4). Plants injected in the central part of the pseudostem (diameter-wise) had a mean death of $11.5 \pm 2.4$ and that was not significantly different from the mean death of $13.0 \pm 1.2$ for plants injected in the peripheral part of the pseudostem (tangential wise) (Table 5). Similarly, sucker development in plants injected diameter wise $(1.3 \pm 0.8)$ was not significantly different from that of plants injected tangential wise $(0.8 \pm 0.5)$. Out of all the plants in the reproductive stage treated, regardless of the herbicide injected and angle of injection, 13.3 \pm 1.0 plants had died by the end of the experiment, a number that was not significantly different from $11.3 \pm 2.4$ plants that died out of the vegetative plants that were injected (Table 5). Similarly, the number of new suckers that developed from injected plants in the reproductive stage $(1.3 \pm 0.7)$ was not significantly different from the number of new suckers that developed from plants in the vegetative stage $(0.8 \pm 0.5)$.

Stump application. All the corms treated with the 2 herbicides started rotting three weeks after application and by the $10^{\text {th }}$ week a complete decay of the treated corm was observed (Table 6). None of the treatments with Roundup killed off all the daughter suckers. Although the sucker leaf lamina edges started showing signs of drying during the first 4 WAA, at 6 WAA new healthy leaves had been formed. In contrast, a $2 \mathrm{ml} \mathrm{2,} \mathrm{4-D}$ application killed the daughter suckers. However, at 10 WAA some re-sprouting from remaining live parts of daughter sucker corms was observed. The re-sprouting suckers could however easily be removed from the soil with a knife/machete or even by hand, as they were not firmly attached to the decaying corms of the daughter suckers.

\section{CONCLUSIONS AND RECOMMENDATIONS}

Both 2,4D and Roundup can be used for the destruction of banana plants. This could be a breakthrough in destroying infected banana plants especially Xanthomonas wilt infected plants where destruction of the infected plantations is recommended for control of the disease. It would save the farmers from tedious and time consuming manual removal of the infected mats. A team of two people, one person making holes in the pseudostems (with a metal rod) and the other person injecting the herbicide solution, can inject 215 pseudostems hour ${ }^{-1}$. This makes the approach quick and effective. If adopted by farmers, the herbicide approach will significantly increase the number of plants destroyed compared to manual removal using machetes and hoes. 
However, consumption of herbicide contaminated banana and fruit parts by humans and animals may be harmful. Therefore removal of all fruits from plants within the treatment area prior to treatment is advised (Sommer, 2000 and Anonymous, 2004). In addition, it is advisable not to harvest any fruit or plant materials from the treated mats following injection and to prevent livestock from consuming treated plant materials. Care should also be taken when applying/injecting the herbicides in mixed banana cropping systems to prevent the chemicals to come in contact with other crops. In or on soil 2,4-D is degraded within a month, while Roundup has no persistence (Daniel et al., 1992). However, soil characteristics and ambient temperature could influence the degradation of 2, 4-D.

2,4-D is more effective in action and cheaper in cost than Roundup and is thus recommended for small scale farmers. 2,4-D costs US\$7 per liter (or 13,000 Uganda shillings), while 'Roundup' costs US\$9 per liter (or 15,000 Uganda shillings). The recommended herbicide concentration and height of injection is $1.6 \mathrm{ml}$ and $2.0 \mathrm{ml}$ of the original concentrate of 2,4D and Round up respectively, at $100 \mathrm{~cm}$ above the ground. Stump application is less effective in controlling sprouting and is thus not recommended. After all it requires more time to cut down the pseudostem than to make a hole in the cut pseudostem/corm surface.

\section{ACKNOWLEDGEMENTS}

The authors would like to acknowledge the financial support from the Flemish Association for Development Co-operation Technical Assistance (VVOB) and the Belgian Directorate General for Development Cooperation (DGDC). The authors would also like to thank Mr. Ronald Ssemakadde for helping with the collection of field data.

\section{REFERENCES}

Anonymous, 2002. Unsuitable for use - Profile of paraquat. Pesticides News No. 56, June 2002, pp. 3-5. http://www.pan-uk.org/ pestnews/pn56/pn56p3.htm
Anonymous, 2004. Banana Bunchy Top Disease in Hawaii: Removal of Diseased Banana Plants. University of Hawaii at Manoa. URL: http:// www2.hawaii.edu/ banana/Roundup.html.

Daniel, L.D., Dallas, E. P. and David, L. R. 1992. Residual Herbicides, Degradation, and Recropping Intervals. Crops and Soils-5-2 (Herbicides) C-707; Kansas State University Agricultural Experiment Station and Cooperative Extension Service).

Eden-Green, 2004. How can the advance of banana xanthomonas wilt be halted? InfoMusa 13(2): 38-41.

Lindsay, S., Pattison, T. and Murad, Z. 2003. Eradicating banana crops with herbicide injection for better IPM and environmental outcomes. Agency for Food and Fibre Sciences, Horticulture. September 2003, Issue 33. http://www.dpi.qld.gov.au/bananatopics/ 12423.html

Martinez, J.A., Yamashiro, T. and Oliveira, D.A. 1988. Desbaste da bananeira por meio de palitos de madeira impregnados com herbicida. (Banana pruning with wood pins impregnated with herbicide). In: Anais. Congreso Brasileiro de Fruticultura, Campinas, 1987/09, Sociedade Brasileira de Fruticultura., Campinas (BRA). pp. 155-160.

Robinson, J.C. 1995. Systems of cultivation and management. In: Gowen, S. (Ed.), pp. 15-65. Bananas and Plantains. Chapman \& Hall. London, UK. 612pp.

Sommer, A. 2000. State prepares to destroy much of Kauai banana crop. Wednesday, May 3, 2000. Honolulu Star-Bulletin. http:// starbulletin.com/2000/05/03/news/story4.html Tushemereirwe, W., Kangire, A., Smith, J., Ssekiwoko, F., Nakyanzi, M., Kataama, D., Musiitwa, C., Karyaija, R. 2003. Outbreak of bacterial wilt on banana in Uganda. Infomusa (FRA) 12(2):6-8.

Yirgou, D., Bradbury, J.F. 1968. Bacterial wilt of Enset (Ensete ventricosum) incited by Xanthomonas musacearum sp. n. Phytopathology 58:111-112.

Yirgou, D., Bradbury, J.F. 1974. A note on wilt of banana caused by the enset wilt organism Xanthomonas musacearum. East African Agricultural and Forestry Journal 40:111114. 